Earth Common Journal Special Issue

$e^{3}=$ earth education economics

1st PRME Canada Regional Meeting held on June 12, 2013

MacEwan University, School of Business

Volume 3, Number 2, September 2013

\title{
Sustainability through Urban Gardening
}

Sherece Burma, Molly Kassian, Nick Larson, Ethno-videographers*

Tami Ambury, Writer*

MacEwan University, Canada

\begin{abstract}
Three visions of attaining sustainability through urban gardening - at the individual, community, and city level - are explored visually by MacEwan University Design Studies students-Molly Kassian, Nick Larson, and Sherece Burma-in their final project for Visual Communications Photography (VCPH) 340, Documentary Photography. This article emphasizes the process through which these students decided upon their project, located and interviewed their subjects, and created their visual composition. It also outlines the students' increased awareness of, interest in, and ease with which urbanites and suburbanites can find or grow their own food.
\end{abstract}

\section{Introduction: The shift from non-renewable to renewable food}

While globalization of our food system has resulted in abundant food choices at relatively low prices, there is reason to believe that a) this may end soon with increases in oil prices, and b) such globalization adds to the very real climate-related challenges we face. According to former chief economist at CIBC World Markets, Jeff Rubin, living in an era of triple-digit oil prices (at the time of writing, oil is selling at $\$ 104$ per barrel) is 
most likely expected to dramatically alter our global search for food (Rubin, 2009, p. 219). The food most North Americans consume "typically travels between 1,500 and 3,000 miles from farm to plate. The distance had increased by up to 25 percent between 1980 and 2001," (Smith \& MacKinnon, 2007, p. 3) when this study was published by the Leopold Center for Sustainable Agriculture at Iowa State University. While Canada continues to be a net exporter of food, particularly of grain products, our relatively harsh climate, limited growing season, and demand for all types of produce, regardless of the season, means that approximately 80 percent of our produce is imported, reports Canadian Produce Marketing Association, an Ottawa-based non-profit organization (CBC, April 26, 2011).

For Rubin, the energy consumption from the industrialized food system led him to a striking conclusion: "My food was much more non-renewable than renewable. The young men in the oil patch were doing more to feed me than the farmers" (p. 121). When oil prices rise, the cost of food so "marinated in oil" (Benjamin, 2011, p.9), as coined by American seed expert Tom Stearns, must also soon follow suit. Those with extra disposable income may be able to absorb these additional costs in the short term, but such costs may be unsustainable in the long term for most Canadians.

And if that is not enough to motivate us to find home-grown solutions, catastrophic rainfall events in Southern Alberta and in the Toronto-Mississauga area in the summer of 2013 reinforce that climate change is not to be ignored. Given this dire situation, now is the time to act positively to reduce our own carbon footprint, to minimize our own impacts on this changing climate. One way to make this happen is to take control of our own food supply - whether supporting local farmers or learning to garden, even at the urban level. During World War II, for instance, the US Secretary of Agriculture called for the establishment of "Victory Gardens" to ensure the American food supply. Control of our own food supply is a reasonable societal goal.

\section{The Project}

James Parker, instructor for VCPH 340, Documentary Photography, at Grant MacEwan University, assigned a final project requiring students to produce a short documentary to present the last day of their Winter 2013 class. Students were assigned groups and topics the same day. To complete this assignment, Molly Kassian, Nick Larson, and Sherece Burma produced the short documentary film, Sustainability Through Urban Gardening. Their project required them to research, analyze, and document urban gardening at three levels - city, community, and individual. They identified five key 
questions to direct their interviews, questions they believed would raise the issues they considered significant. These questions included:

- What does sustainability mean to you?

- Why did you choose to participate in urban agriculture?

- What benefits do you gain from your participation in urban agriculture?

- What are some of the challenges you've faced with urban agriculture?

- How do you hope your involvement in urban agriculture affects things on a larger scale?

\section{The Composition}

The group determined that their composition would include a combination of still and video images with minimal use of text in order to emphasize the perspectives of their interview subjects. Both still and video images were recorded on Nick's Canon 5D Mark 3-a digital camera used to film sections of Iron Man and The Avengers-and Sherece's Canon 7D - used to film the opening sequence of Saturday Night Live. Once filming was complete, Nick imported the images into Adobe Light Room for colour, contrast and sharpness correction and then exported these corrected images into iMovie to apply final edits.

After each choosing and editing in Adobe Light Room five of their own still photos, the group members then looked at the coherence of the message by answering the five main research questions, hoping to give roughly equal time to each of their participants within a 12-13 minute video. As the interviews were structured in this fashion, the group found it relatively easy to fit together each of the final video and still photography sections.

With more filming experience than Sherece and Molly, Nick was assigned the role of primary interview photographer, with either Molly or Sherece assuming the role of interviewer during sessions with their subjects. This decision was, at least in part, steered by the fact they felt it would be neither comfortable nor natural for their interviewees to look directly at the camera, deciding that this interviewer off-camera approach would be the most effective.

\section{Minimal Typography - A design conscious choice}

When assigned this project, Molly, Nick and Sherece made the "design-conscious choice" (Molly interview, April 23, 2013) to limit the text within their production to a 
series of five primary questions, questions directed to each of their interviewees. They felt avoiding large blocks of text within their project would more readily capture the interest of their audience, providing an easy and effective learning experience. As students, they had been exposed to presentations with paragraphs of text that were both extensive and uninteresting. According to Sherece, their group hoped to do something different.

The less text that you can include while still communicating what you want the viewer to see, the better...We've been kind of trained for the last three years that minimalism is the key to good design. You don't want to really notice it. You don't want to have people reading and reading and reading and then saying, 'Oh, that's what you meant to do!" They want to see it visually like "that" (snapping her fingers)... it's got to hit you just by looking at it (Sherece interview, April 24, 2013).

Their decision is certainly backed by science. Researchers at 3M Corporation found that humans "process visuals 60,000 times faster than text" (Parkinson, 2012, para. 17). In fact, as Parkinson points out "Visuals are not only excellent communicators but also quickly affect us psychologically and physiologically”(2012, para. 6). Indeed, this may be a primary reason that images stick with us longer, they are more deeply processed due to their interconnectedness with our many other experiences.

Rather than have text speak, then, Sherece, Molly, and Nick wanted to have their interviewees' words and images speak for themselves. Where there were gaps or definition issues, the group decided to answer these questions themselves through the careful scripting of answers they recorded of one another during their final day of edits. Their decision to opt for dialogue over text is supported by Barthes, French literary theorist, who says that "in film, ...dialogue functions not simply as elucidation but really does advance the action by setting out, in the sequence of messages, meanings that are not found in the image itself' (Barthes, 1977(1964), p. 41).

\section{The Interview Process}

The group quickly recognized the need to limit the scope of their topic from sustainable agriculture to something more defined. While discussing possible options, Sherece informed her group members of a friend who had helped establish the Edmonton "guerilla gardeners," a group of individuals who decided their form of urban graffiti would involve the planting of empty urban land. When this friend moved to Calgary, he continued to guerrilla garden and also embraced window farming, "a vertical, indoor garden that allows for year-round growing in almost any window. It lets plants 
use natural window light, the climate control of your living space, and organic "liquid soil" (Windowfarms, 2013, para. 1).

Agreeing that urban gardening would be their topic, the group divided the project into three sections, with Sherece responsible for the individual/personal level of urban gardening, Molly the community level, and Nick the regional level. Sherece put out a call on social media to find an individual gardening within city limits and was quickly rewarded by a referral to an acquaintance, and, as luck would have it, the wife of her high school social studies teacher.

Their initial interview with Christie provided them with a great deal of needed background and information on the topic of urban gardening. Christie was passionate about the topic and more than willing to share her knowledge about both windowsand suburban gardening, whether in blog form (http://crazysuburbangardener. blogspot.ca/), or in this instance, in an interview setting. While her backyard garden may not be extraordinarily unusual in Edmonton, her decision to extend her garden into the front yard, to take out portions of her Kentucky Bluegrass lawn, and to replace it with flowers and vegetables, seemed to amuse and concern her more conservative neighbours. Of Christie, Molly said: "She was so willing to go against the grain which, I think, is something in our society that is a problem because everybody wants to conform to a certain way of life" (Molly interview, April 23, 2013). Christie insists that knowing where her food comes from, that it does not have pesticides added, and that she can teach her children about food are all motivating factors in her choice to urban garden.

For her part, in work she had done in another class on the Edmonton Food Bank the year prior, Molly learned about local community gardens, some of which donate to the Food Bank. In order to track down an individual to interview, Molly e-mailed Sustainable Foods Edmonton and visited a number of the snow-covered 72 plus community gardens in Edmonton. After contacting several of the community garden organizers, she eventually came upon Marcus at the Strathcona Rail Community Garden as the subject of her section within the video.

\section{Findings}

Markus farms a 240 square-foot plot of land at Strathcona Rail but is able to produce approximately 150 pounds of food per year. Although many individuals living in an urban environment may not actually possess their own land, community gardens provide a very inexpensive option - $\$ 20$ per plot at Strathcona Rail-for people interested in urban gardening.

ECJ Volume 3, No. 2, 2013: $\mathrm{e}^{3}=$ earth education economics 
Molly pointed out a further benefit of community gardening-a traditional sense of community. During our interview, she identified the challenges of people meeting in a larger urban setting. Young people meet at bars. If they don't drink, they may have trouble meeting like-minded individuals. It is equally challenging for older people. Molly put it well when she stated that Markus "makes friends in his community garden. He gets to hang out with people in the summer, to exchange gardening information or whatever it is. It's not only people from all over the city, it's ... from within your community. It creates an old fashioned sense of community" (Molly interview, April 23, 2013). In fact, community psychologists are beginning to recognize the value of community gardening to increase a sense of community, to encourage socializing among neighbours and to decrease isolation through sharing of stories, tools, knowledge, ideas, culture, and produce" (Wakefield et al., 2007, p. 98).

While searching the Internet for inspiration for his section, Nick was particularly attracted to the effective use of colour and design in the Riverbend Gardens website, two elements critical for design students. Janelle Herbert and her husband are the third generation of famers currently living on and working at Riverbend Gardens, a 120-acre farm on the North Saskatchewan River close to Fort Saskatchewan but still within Edmonton city limits. Their 20 or more varieties of vegetables are sold at local farmers' markets in Edmonton, St. Albert, Fort Saskatchewan, and Sherwood Park.

Unfortunately, Riverbend Gardens is currently dealing with city plans to bisect their farm with a multilane highway, cutting through the centre of their greenhouses. In addition to the potential loss of agricultural land within city limits, this proposed road will, according to Janelle, demolish a patch of old growth forest on Riverbend Gardens land, currently used by First Nations groups for traditional ceremonies and education.

With regards to this potential loss, Nick stated:

I mean, the city said they're going to tear down her farm and I think that's a pretty big issue. You have an incredible operation like that that's not going to exist anymore. I mean, there's other places for highways and there's other places for million dollar homes on the river. To have an operation like that that's on the river that's using water out of the river to run their farm sustainably like that, I mean, that's amazing... It's such a shame that they're going to get rid of it. (Nick interview, April 24, 2013) 


\section{Discussion}

Edmonton is certainly no exception to the 1,500 to 3,000 miles rule identified earlier, particularly as we are the northernmost large urban area in North America. Rarely do we find bananas, oranges or pineapples growing abundantly in our city. Most frequently, labels on our produce indicate that it has travelled to us from Florida, California, Mexico or even further afield.

Nick pointed to the comparative transportation distances of food at Riverbend Gardens versus most produce we receive in Edmonton, stating "So you move it 30 feet into a storage shed. I'd much rather that than have it on a series of containers, freighters and trains. When you think again about fuel coming from somewhere like Israel to here shipping produce, that's crazy" (Nick interview, April 24, 2013).

While implementing the 100-mile diet in Edmonton may be a bit of a stretch for most of us, Edmonton's Food and Urban Agriculture Advisory Committee-comprised of a number of farmers, developers, academics, and community organizers-have put together their strategy for moving closer to a sustainable food system in this community. Ultimately, they recognize that the "elements of that food system include preserving some prime agricultural land for farming, creating space for urban food production, creating access to local markets, stimulating consumer access to local produce as well as awareness and excitement around that produce, and reducing food waste" (Food and Urban Agriculture Advisory Committee, 2012, p. 65). Recognizing the decline in conventional farming, often at the feet of urban development and sprawl, the committee hopes to take advantage of the "growing interest in urban farming to encourage more young farmers" (Food and Urban Agriculture Advisory Committee, 2012, p. 48) and to provide the education, incentives, and business development essential to support this emerging group.

Molly, Nick and Sherece's project illustrates the relative possibility of achieving the above-stated goals at all levels of urban gardening-individual, community, and local. As Molly put it during her interview, "you think you need to move out to the country to have your own farm" (Molly interview, April 23, 2013). In reality, however, there are more realistic options for urban dwellers. If you don't have the space for a back (or front) yard garden, you can window garden or join a community garden. By 1944, "between 18 and 20 million families had victory gardens that collectively provided $40 \%$ of the total American vegetable supply" (Lawson 2005, p. 171). This remarkable achievement is ample proof of concept, showing that with proper motivation and the necessary will, people can indeed create a sustainable food supply by way of gardening. If 
time is an issue, you can still support urban agriculture-thereby dramatically reducing the oil required to transport the produce you consume-by taking a trip to one of many farmers' gardens in most urban centres and supporting local famers such as Riverbend Gardens.

*Ethno-videographers: Sherece Burma, Molly Kassian, and Nick Larson: The ethno-videographers for the project were students of the Design Studies program at Grant MacEwan University. They collaborated to produce the video for their final project for Visual Communications Photography (VCPH) 340, Documentary Photography.

*Writer: Tami Ambury is a second year student in the Bachelor of Communication Studies program at MacEwan University. She also has a Bachelor of Arts in Political Science and a Master of Arts in History from Simon Fraser University. Her thesis is entitled Continuity and Change in the Selection Process of the Ottoman Grand Veqirs, 1368-1789. Tami currently sits on the editorial board of Earth Common Journal and is a research assistant on projects dealing with disaster communication on social media.

\section{References}

Barthes, R. (1977(1964)). Rhetoric of the Image. In Image, Music, Text (pp. 32-51). New York: Hill and Wang.

Benjamin, C. (2011). Eco-Innovators: Sustainability in Atlantic Canada. Halifax, N.S.: Nimbus Publishing.

Burmark, L. (2004). Why Visual Literacy? Retrieved from http://mattech.net/COTF\%20CD/WhyVisualLiteracy.pdf

Christie. (2013). Crazy Suburban Gardener. Retrieved from http:/ / crazysuburbangardener.blogspot.ca/

Food and Agriculture Advisory Committee. (2012, October). fresh: Edmonton's Food and Urban Agriculture Strategy. Retrieved from http://www.edmonton.ca/city_government/documents/FRESH_October_2012.p df

Lawson, L. J. (2005). City bountiful: A century of community gardening in America.

Berkeley, CA: University of California Press.

Parkinson, M. (2012). The Power of Visual Communication. Retrieved from 
http://www.billiondollargraphics.com/infographics.html

Produced, made or prepared in Canada? Determining what is and is not a product of

Canada. (2011, April 26). Retrieved from

http://www.cbc.ca/news/canada/story/2011/04/26/f-product-label-fresh-

produce.html

Rubin, J. (2009). Why Your World Is About To Get A Whole Lot Smaller: Oil and the End

of Globalization. New York: Random House.

Smith, A. \& MacKinnon, J.B. (2007). The 100-Mile Diet: A Year of Local Eating. Toronto: Vintage Canada.

Wakefield, S., Yeudall, F., Taron, C., Reynolds, J., \& Skinner, A. (2007). Growing urban health: Community gardening in South- East Toronto. Health Promotion International, 22, 92-101.

Windowfarms. (2013). What is a windowfarm? Retrieved at http://www.windowfarms.com/what-is-a-windowfarm/ 